\title{
PEMANFAATAN SERAT IJUK PADA GENTENG BETON DENGAN MENGGUNAKAN BATU APUNG SEBAGAI BAHAN TAMBAH TERHADAP MUTU GENTENG BETON
}

\author{
Novi Susiawati, Irza Ahmad, Amos Neolaka
}

\begin{abstract}
This research aim to know existence of optimum value and difference quality of concrete tile using palm tree fibred as addition material. This Research place in Hall Research Substance Laboratory On Duty Industry of DKI Jakarta. Research method is experiment method. There is five treatment type, that is : $0 \% ; 1 \% ; 1,5 \% ; 2 \%$ and $2,5 \%$ Fibred of palm tree from weight of cement. Amount. of object test entire/all 50 object test with each treatment 10 object test.

Data have homogeneous and normal Distribution to. Examination by ANAVA is obtained by one way of $\mathrm{F}$ hitung $>\mathrm{F}$ tabel so that $\mathrm{H} 0$ refused, for the limber burden $30,35>2,58$ and the absorption irrigate $120>2,58$. While test $t$ for the got limber burden of thitung $>$ ttabel or 28,66 $>2,82$ hence $\mathrm{HO}$ refused. Medium absorption irrigate thitung $<\mathrm{t}$ tabel or $-0,324>2,82$ hence $\mathrm{HO}$ accepted. Obtained. of result of research of $\mathrm{t}$ here are difference quality of concrete tile with use of variation of different palm tree fibred at optimum value and concrete tile quality of concrete tile with variation of different palm tree fibred bigger than SNI.

Result of research concrete tile by using palm tree fibred with different variation, can yield average value of limber burden fulfilling Standard of Indonesia National SNI with the result mounting. For the absorption irrigate, progressively increase percentage palm tree fibred used hence the excelsior assess absorption irrigate concrete tile. use palm tree fibred as addition at concrete tile can be used until percentage $1 \%$ palm tree fibred from weight cement, with value of limber burden 152,3 kgf and absorption irrigate 9,98\% fulfilling Standard of National of Indonesia of according to SNI 03-0096-1999.
\end{abstract}

Kata kunci : palm tree fibred

$\begin{array}{lcr}\text { Novi Susiawati } & \text {, Irza Ahmad, Ir..MT } & \text { Amos Neolaka , Drs,. MPd } \\ \begin{array}{l}\text { Alumni Jurusan Teknik Sipil } \\ \text { Fakultas Teknik }\end{array} & \text { Staf Pengajar Jurusan Teknik Sipil } & \text { Staf Pengajar Jurusan Teknik Sipil } \\ \begin{array}{l}\text { Universitas Negeri Jakarta, 13220 } \\ \text { Fakultas Teknik }\end{array} & \text { Fakultas Teknik } \\ \text { Universitas Negeri Jakarta, 13220 } & \text { Universitas Negeri Jakarta, 13220 }\end{array}$

Pemanfaatan Serat ljuk pada Genteng Beton dengan Menggunakan Batu Apung sebagai Bahan Tambah terhadap Mutu Genteng Beton, Novi Susiawati, Irza Ahmad, Amos Neolaka 


\section{PENDAHULUAN}

Sejalan dengan peningkatan pembangunan yang dilaksanakan dewasa ini mengakibatkan membawa konsekwensi semakin meningkatnya kebutuhan masya-rakat, pemerintah maupun pihak swasta mengambil langkah-langkah kebijaksanaan diberbagai bidang. Khusus dibidang industri, kebijaksanaan pemerintah diarahkan kepada pengembangan industri yang menghasilkan produk dengan memanfaatkan bahan-bahan yang dapat diperoleh di dalam negeri. Salah satu jenis industri yang dikembangkan adalah industri genteng beton.

Genteng beton adalah unsur bangunan yang dipergunakan untuk atap dibuat dari beton yang merupakan campuran yang merata antara semen Portland atau seje-nisnya dengan agregat dan air memakai atau tanpa memakai pigmen, tidak termasuk genteng dengan bahan perekat aspal dan genteng dengan memakai serat asbes atau serat lainnya. [ SNI 03-0096-1999, h.1.]

Genteng beton merupakan komponen bangunan yang berfungsi sebagai atap bangunan perumahan, gedung perkantoran dan sebagainya. Melihat fungsinya ini, maka kegiatan pembangunan yang semakin meningkat akan membawa dampak positif, maka perlu diupayakan pemilihan alternatif seperti pemanfaatan potensi sumber daya alam dalam rangka diversifikasi bahan baku.

Pembangunan rumah dengan menggunakan genteng beton, harus memperhitungkan kekuatan kerangka konstruksi kayu yang menyangga beban atap tersebut. $\mathrm{Hal}$ ini salah satu yang membuat biaya pembangunan perumahan cukup tinggi, yaitu dalam rangka pengadaan kayu yang cukup kuat daya dukungnya sekurang -kurang-nya kayu mutu kelas II. Pemerintah dari berbagai departemen yang terkait dengan masalah pembangunan perumahan, tak henti-hentinya mencari alternatif untuk menekan biaya pembangunan perumahan bagi masyarakat luas.

Pada penelitian sebelumnya pernah dilakukan yaitu pembuatan genteng beton [Manggasa, 1996, h. 35], menjelaskan penggunaan batu apung Pumice sebagai bahan subtitusi agregat halus pasir dalam pembuatan genteng beton menunjukkan hasil positif terhadap peng-urangan bobot genteng. Hal ini dimungkinkan adanya kandungan silika bentuk amorf yang bersifat sebagai silika aktif yang apabila dicampur dengan bahan 
pengikat hidrolis dan air akan membentuk senyawa hidrat yang padat dan keras [Manggasa, Andarias, 1993, h.3], dan adanya pori-pori pada batu apung sebagai akibat keluarnya gas-gas dari lelehan magma pada saat berlangsungnya proses pembekuan. Penggunaan batu apung sebagai bahan subtitusi agregat halus pasir pada genteng beton, menunjukkan hasil pengujian kuat lentur genteng beton belum memenuhi syarat mutu beban lentur.

Penelitian sebelumnya pernah dilakukan penambahan serat alami pada campuran adukan beton seperti penambahan serat ijuk pada campuran pembuatan paving block oleh saudara Ulumudin [Ulumudin, 2004, h.3] penambahan serabut kelapa pada campuran pembuat-an genteng beton oleh saudara Ramoko [Ramoko, 1996, h.45] dan penambahan ampas tebu Bagase oleh saudara Irfan [Irfan, 2003, h.60] menjelaskan bahwa penggunaan serat alami dapat digunakan sebagai bahan pengisi dan dapat mengadakan ikatan dengan semen.

Kemampuan ikatan ini karena dipengaruhi oleh kemampuan serat alami dalam menyerap air. Semakin besar kemampuan suatu serat dapat menyerap air maka akan menghasilkan kekuatan yang lebih tinggi bila dibandingkan dengan yang tidak dapat menyerap air. [Balai Penelitian Bahan, 1996, h.19]

Untuk memperbaiki sifat dan meningkatkan mutu genteng beton dengan menggunakan batu apung sebagai bahan tambah dapat dilakukan dengan cara penambahan serat alami. Salah satu bahan tambah berupa serat alami yang sering di jumpai seperti serat ijuk yang relatif lebih murah dari pada serat baja serta lebih mudah di dapat dan lebih ringan.

Untuk perbandingan penelitian awal tanpa menggunakan mill, ternyata adukan tidak ada pengikatan atau tidak bisa di cetak dan hasilnya hancur. Sehingga penulis mengambil kesimpulan penelitian dengan menggunakan mill seperti pada penelitian terdahulu dengan perbandingan 1 mill : 1 semen portland.

Untuk Faktor air semen yang akan digunakan pada genteng beton pada penelitian awal, pertama yaitu dengan menggunakan faktor air semen 0,45 ternyata adukan terlalu kering tidak bisa dicetak, lalu dibuat dengan factor air semen 0,65 dan ternyata adukan

Pemanfaatan Serat ljuk pada Genteng Beton dengan Menggunakan Batu Apung sebagai Bahan Tambah terhadap Mutu Genteng Beton, Novi Susiawati, Irza Ahmad, Amos Neolaka 
masih tidak bisa dicetak, kemudian air ditambah lagi sampai faktor air semen 1 dan hasilnya adukan seperti pasta dan bisa dicetak.

Berdasarkan kondisi tersebut perlu dilakukan penelitian pemanfaatan serat ijuk sebesar $0 \% ; 1 \% ; 1,5 \% ; 2 \%$ dan 2,5\% terhadap berat semen dengan panjang serat $2 \mathrm{~cm}$ dan menggunakan 2,5 batu apung serta menggunakan mill dengan perbandingan 1 mill : 1 semen portland terhadap mutu genteng beton dengan faktor air semen 1.

\section{METODA}

Prosedur penelitian di laboratorium adalah berdasarkan cara uji mutu genteng beton menurut SNI 03-0096-1999.

Prosedur kerja penelitian ini meliputi :

Tahap Pemeriksaan Bahan.

Pemeriksaan bahan sepeti semen, pasir dan air dilakukan agar diketahui sifat-sifat dan kandungan yang ada di dalam bahan tersebut, yaitu :

Semen Portland

Semen tidak dilakukan pengujian karena semen yang digunakan semen Tiga Roda Type I yang telah memenuhi standar persyaratan Semen Portland.

Agregat Halus Pasir

Pengujian Gradasi Pasir

Pengujian Indeks Kekerasan Pasir

Pemeriksaan Zat Organik Dalam Pasir

Pengujian Kadar Lumpur

Pengujian Analysis Spesifik Gravity dan penyerapan air pasir.

Agregat Halus Batu Apung

Batu apung yang digunakan berasal dari cilegon. Selanjutnya batu apung dihaluskan dengan proses pengilingan dengan Ballmill yang dilakukan di Lembaga IImu Pengetahuan Indonesia, Pusat Penelitian Metalurgi, Kawasan PUSPITEK Serpong Tanggerang Banten. Setelah dilakukan penggilingan dengan

Ballmill, batu apung di ayak dengan menggunakan ayakan berukuran lubang 1,0 
$\mathrm{mm} ; 2,4 \mathrm{~mm}$ dan 4,8 mm. Pengayakan ini bertujuan untuk memenuhi syarat kehalusan agregat halus.

Agregat halus batu apung merupakan agregat ringan, untuk agregat ringan harus memenuhi syarat menurut ASTM C.330-80.

Pengujian Gardasi Batu Apung

Pemeriksaan Zat Organik Dalam Batu Apung

Pengujian Analysis Spesific gravity Dan Penyerapan Air Batu Apung

ljuk Serat ljuk

1 Pengujian Penentuan Kadar Air

2 Pengujian Kadar Kotoran

Air

Air yang digunakan dalam penelitian ini adalah PAM, maka tidak dilakukan pemeriksaan karena telah memenuhi standar persyaratan.

\section{Tahap Pembuatan Benda Uji}

Dalam pembuatan genteng beton ini digunakan standar SNI 03-0096-1999. Pada penelitian ini dibuat benda uji dengan perbandingan berat yaitu mengguna-kan campuran 1 sp : 1,5 ps : 2,5 batu apung : 1 mill : 0\%; 1\%; 1,5\%; $2 \%$ dan 2,5\% serat ijuk dari berat semen. Dalam penelitian ini dibuat benda uji dengan ukuran panjang $42 \mathrm{~cm}$, lebar $34 \mathrm{~cm}$ dan tebal 1,2 cm dengan faktor air semen 1.

Proses Pembuatan Genteng Beton

1. Tahap Persiapan Bahan :

a. Batu apung yang sudah digiling dan pasir, masing-masing diayak dengan menggunakan ayakan berukuran lubang $1,0 \mathrm{~mm}, 2,4 \mathrm{~mm}$ dan $4,8 \mathrm{~mm}$, kemudian ditimbang sesuai dengan perbandingan yang direncanakan.

b. Serat ljuk dilakukan pembersihan dari kotoran-kotoran, setelah dibersihkan selanjutnya dipotong-potong sepanjang $2 \mathrm{~cm}$ dan ditimbang sesuai dengan perbandingan yang direncanakan.

Pemanfaatan Serat ljuk pada Genteng Beton dengan Menggunakan Batu Apung sebagai Bahan Tambah terhadap Mutu Genteng Beton, Novi Susiawati, Irza Ahmad, Amos Neolaka 
c). Semen yang akan digunakan ditimbang sesuai dengan perbandingan yang direncanakan.

2. Tahap Pencampuran Bahan :

a. Dengan perbandingan tertentu, batu apung, pasir, mill dan semen dicampur dengan serat ijuk, kemudian diaduk secara merata sampai homogen.

b. Campuran tersebut kemudian dimasukan kedalam alat pencampur molen dan ditambahkan air sedikit demi sedikit, kemudian diaduk sampai homogen atau mencapai konsistensi tertentu untuk siap dicetak.

3. Tahap Pencetakan Genteng Beton

Pada umumnya pembuatan genteng beton ada dua cara, yaitu pencetakan cara kering dan pencetakan dengan cara basah.

Pencetakan cara kering ialah menggunakan campuran kering atau lengas tanah, sedangkan cara pencetakan basah adukan yang digunakan berupa pasta basah . Pada penelitian ini menggunakan pencetakan cara basah.

a. Adukan tersebut selanjutnya dimasukkan ke dalam cetakan dan ditekan dengan mesin press hingga padat. Hal ini akan menyebabkan air yang berlebih dalam adukan akan keluar sehingga genteng beton yang baru di cetak memperoleh kekakuan.

b. Genteng yang telah terbentuk, diangkat dari cetakan dengan hati-hati kemudian dimasukan ke ruang curing.

4. Tahap Curing Genteng Beton Pematangan

Tahap curing ada tiga tahap. Curing ini dimaksudkan untuk menjaga kebutuhan air dalam proses hidratasi semen tetap terpelihara, karena pada proses hidratasi akan terjadi penguapan air dalam beton karena panas, maka air yang hilang tersebut berlangsung dengan sempurna [Balai Penelitian Bahan,1996, h. 26]

Tahap-Tahap Curing Genteng Beton : [Balai Penelitian Bahan,1996, h. 27-28]

a. Curing Tahap Pertama :

1 Genteng dimasukan keruangan yang lembab udara dan terlindung oleh tiupan angin dan sinar matahari. 
2 Kemudian diangin-anginkan dalam rak pengering selama 24 jam dengan suhu berkisar $20^{\circ} \mathrm{c}-29^{\circ} \mathrm{c}$ dengan kelembaban udara minimum $70 \%$.

b. Curing Tahap Kedua :

Selanjutnya genteng direndam dalam bak perendam selama \pm 7 hari.

c). Curing Tahap Ketiga :

1 Setelah itu genteng dikeringkan kembali dengan cara diangin-anginkan sampai kering udara didalam ruangan yang terlindung oleh pengaruh matahari langsung.

2 Setelah mencapai umur 28 hari, genteng tersebut sudah dapat dipakai atau dipasarkan.

\section{Tahap Pengujian Benda Uji}

Pengujian beban lentur genteng beton pada penelitian ini mengacu pada SNI 03-00961999. Benda uji yang digunakan genteng beton yang telah berumur 28 hari.

Prosedur Pengujian Beban Lentur Genteng Beton. [SNI 03-0096-1999,, h.5]

a. Persiapan / Peralatan :

1. Mesin uji beban lentur yang memberikan beban secara teratur dan merata dengan system tripot dengan ketelitian $1 \mathrm{~kg}$.

2. Bak air untuk perendaman 10 contoh uji.

b. Cara Kerja :

1. Ambil benda uji sebanyak 10 genteng.

2. Kondisikan benda uji dengan direndam air selama 24 jam, sebelum dilakukan pengujian.

3. Letakan benda uji dalam keadaan basah diatas dua tumpuan yang sejajar dalam arah membujur, penerapan beban dilakukan ditengah kedua tumpuan dimana terletak benda uji melalui tumpuan tetap yang serupa.

Pemanfaatan Serat ljuk pada Genteng Beton dengan Menggunakan Batu Apung sebagai Bahan Tambah terhadap Mutu Genteng Beton, Novi Susiawati, Irza Ahmad, Amos Neolaka 
Semua tumpuan dan permukaan beban harus rata dan harus menyangga panjang benda uji sepenuhnya.

Penyangga tumpuan harus berbentuk bulat dengan jari -jari sekitar $32 \mathrm{~mm}$.

4. Lakukan pembebanan dengan tingkat penambahan beban yang tetap dengan laju $50 \mathrm{~N}$ / detik, hingga genteng patah.

5. Catat pembebanan maksimum pada waktu genteng patah yang ditunjukkan oleh alat kontrol mesin.

6. Hitung rata-rata beban lentur dari 10 buah benda uji.

Prosedur Pengujian Penyerapan Air Genteng Beton. [SNI 03-0096-1999,, h.6]

a. Peralatan :

Oven dengan temperature kerja $200^{\circ} \mathrm{c}$ dengan ketelitian 2 derajat, neraca teknis kapasitas $10 \mathrm{~kg}$ dengan ketelitian $1 \mathrm{gram}$. Bak perendam, lap lembab.

b. Cara Kerja :

1. Siapkan benda uji dalam keadaan kering 10 buah.

2. Keringkan genteng dalam oven pada suhu $110+5^{\circ} \mathrm{c}$ selama 2 jam.

3. Timbang genteng dalam keadaan kering $\mathrm{K}$ gram .

4. Rendam genteng tersebut dalam air selama 24 jam

5. Timbang genteng dalam keadaan basah dengan menyeka permukaan genteng lebih dulu dengan lap lembab, catat berat contoh $W$ gram .

6. Hitung peresapan air genteng dalam \% sebagai berikut :

$$
\frac{W-K}{K} \times 100 \%
$$

7. Hitung rata-rata \% peresapan air genteng. 
ISSN: $1907-4360$

\section{HASIL DAN PEMBAHASAN}

\section{Hasil Penelitian}

1. Deskripsi Data Uji Material

a. Hasil Pengujian Agregat Halus Pasir Cimalaka

Tabel 1. Data Hasil Pengujian Agregat Halus Pasir Menurut SII.0052-80

\begin{tabular}{|c|c|c|c|c|}
\hline No. & Pengujian & Hasil Pengujian & Standar & Keterangan \\
\hline 1. & $\begin{array}{l}\text { Gradasi Agregat } \\
\text { Pasir }\end{array}$ & $\begin{array}{l}\text { - Modulus Kehalusan } \\
\qquad \mathrm{FM}=3,74 \\
\text { - Pasir termasuk Zona II } \\
\text { Pasir agak Kasar }\end{array}$ & $F \cdot M=1,5-3,8$ & $\begin{array}{l}\text { Memenuhi } \\
\text { Standar }\end{array}$ \\
\hline 2. & $\begin{array}{l}\text { Indeks Kekerasan } \\
\text { Butiran Pasir }\end{array}$ & 1,49 & Maksimum 2,20 & $\begin{array}{l}\text { Memenuhi } \\
\text { Standar }\end{array}$ \\
\hline 3. & Zat Organik Pasir & $\begin{array}{l}\text { *Lebih tua dari kuning } \\
\text { muda }\end{array}$ & ${ }^{*}$ Kuning muda & $\begin{array}{l}\text { Memenuhi } \\
\text { Standar }\end{array}$ \\
\hline 4. & Kadar Lumpur Pasir & $2,46 \%$ & Maksimal 5\% & $\begin{array}{l}\text { Memenuhi } \\
\text { Standar }\end{array}$ \\
\hline 5. & $\begin{array}{l}\text { Berat Jenis Dan } \\
\text { Penyerapan Pasir }\end{array}$ & $\begin{array}{l}\text { - Berat Jenis = 1,18 } \\
\text { - Berat Jenis JPK = 1,23 } \\
\text { - Penyerapan = 4,85\% }\end{array}$ & - & - \\
\hline
\end{tabular}




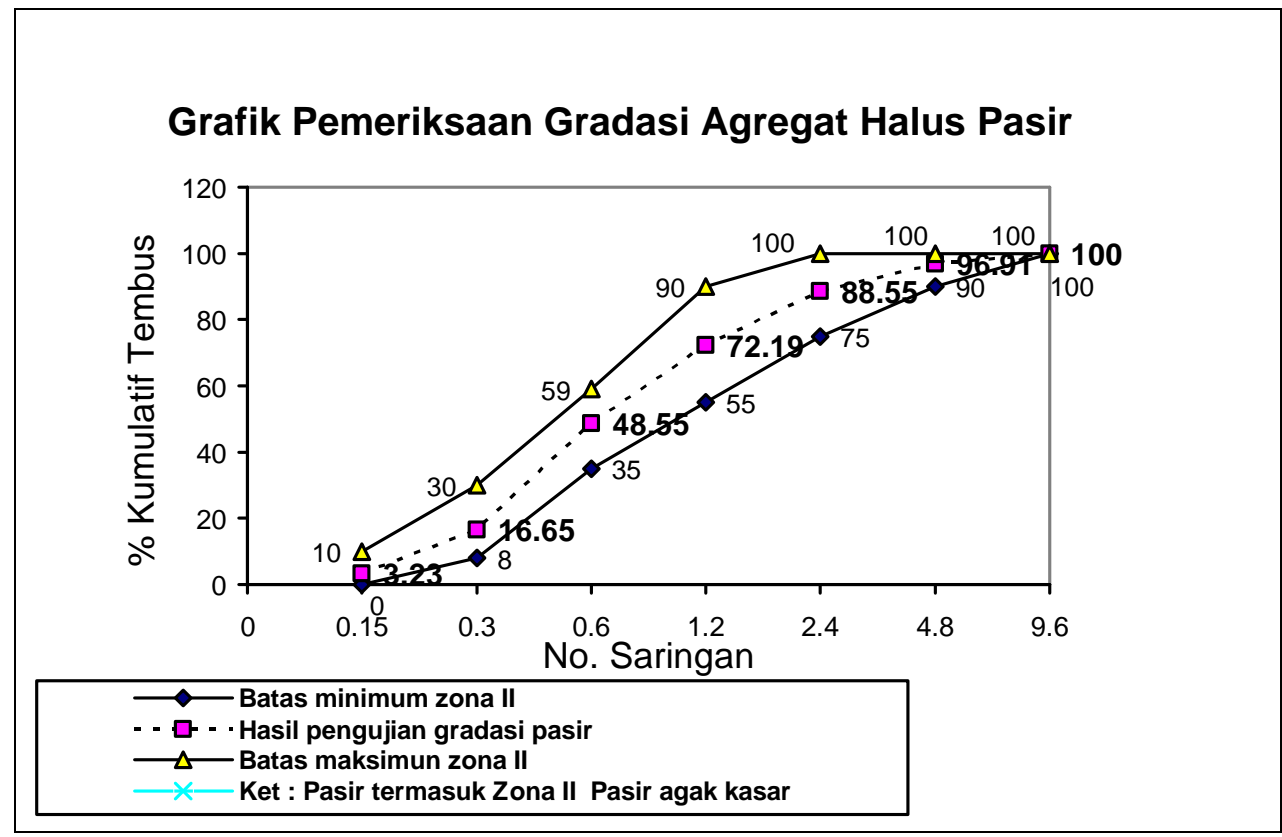

Gambar 1. Grafik Susunan Gradasi Pasir Menurut SK SNI T-15-1990-03.

b. Hasil Pengujian Agregat Batu Apung Cilegon

Tabel 2. Data Hasil Pengujian Agregat Batu Apung Menurut ASTM C.330-80

\begin{tabular}{|c|c|c|c|c|}
\hline No. & Pengujian & Hasil Pengujian & Standar & Keterangan \\
\hline 1. & $\begin{array}{l}\text { Gradasi Agregat } \\
\text { Batu Apung }\end{array}$ & $\begin{array}{l}\text { - Susunan gradasi sesuai } \\
\text { dengan ASTM C.330-80. }\end{array}$ & $\begin{array}{l}\text { - Susunan gradasi } \\
\text { harus sesuai } \\
\text { dengan ASTM } \\
\text { C.330-80. }\end{array}$ & $\begin{array}{l}\text { Memenuhi } \\
\text { standar }\end{array}$ \\
\hline 2. & $\begin{array}{l}\text { Zat Organik Batu } \\
\text { Apung }\end{array}$ & ${ }^{*}$ Kuning muda & $\begin{array}{l}\text { *Lebih tua dari kuning } \\
\text { muda }\end{array}$ & $\begin{array}{l}\text { Memenuhi } \\
\text { standar }\end{array}$ \\
\hline 3. & $\begin{array}{l}\text { Berat Jenis Dan } \\
\text { Penyerapan Batu } \\
\text { Apung }\end{array}$ & $\begin{array}{l}\text { - Berat Jenis = 0,95 } \\
\text { - Berat Jenis JPK = 1,54 } \\
\text { - Penyerapan = 61,55 }\end{array}$ & - & - \\
\hline
\end{tabular}




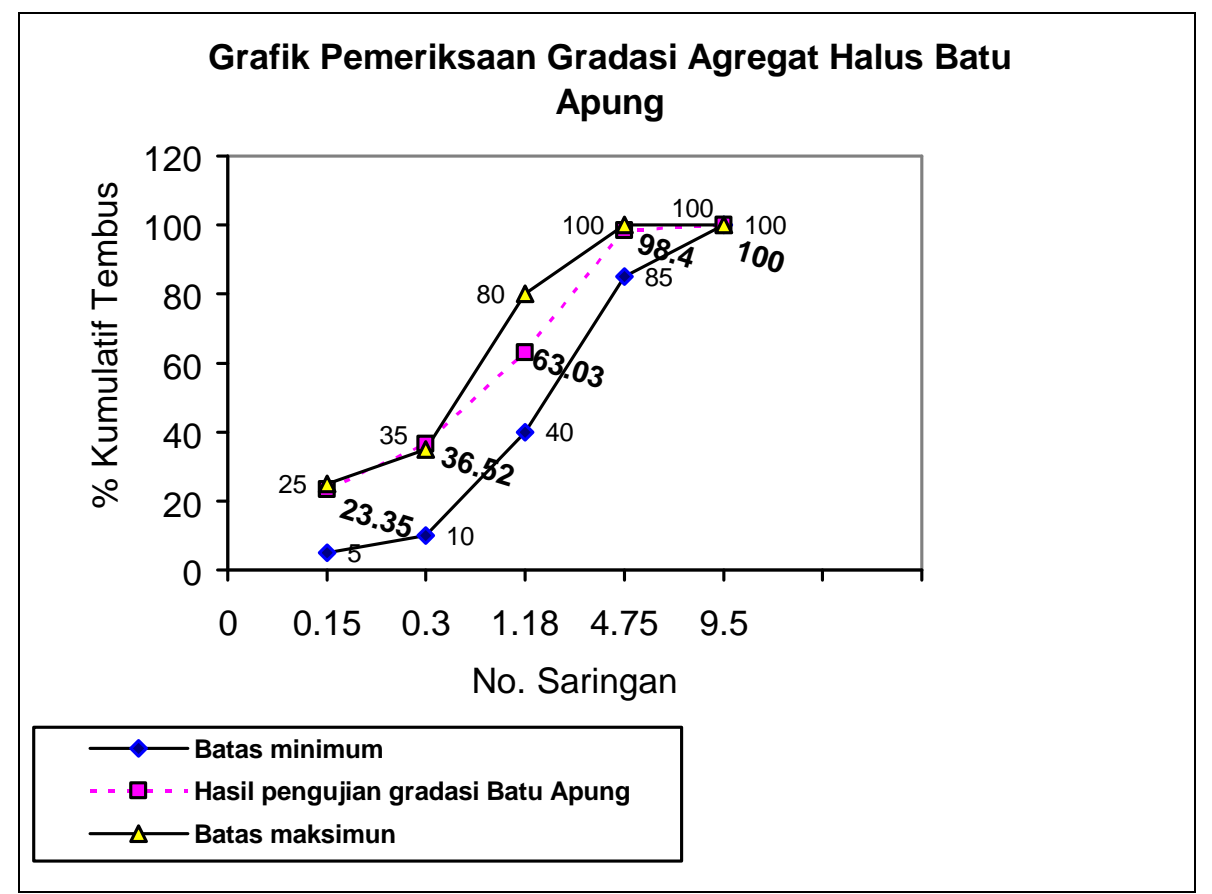

Gambar 2. Grafik Susunan Gradasi Batu Apung Menurut ASTM C.330-80.

c. Hasil Pengujian Serat ljuk

Pada penelitian ini menggunakan serat ijuk yang dipotong-potong sepanjang $2 \mathrm{~cm}$, sesuai dengan standar Genteng ljuk SNI 03 -6027-1999 .

Tabel 3. Data Hasil Pengujian Serat ljuk Menurut SNI 01-1673-1980.

\begin{tabular}{|c|l|c|c|c|}
\hline No. & \multicolumn{1}{|c|}{ Pengujian } & Hasil Pengujian & Standar & Keterangan \\
\hline 1. & $\begin{array}{l}\text { Kadar Air Serat } \\
\text { ljuk }\end{array}$ & $5,6 \%$ & Maksimal 15\% & $\begin{array}{c}\text { Memenuhi } \\
\text { standar }\end{array}$ \\
\hline
\end{tabular}

\section{Deskripsi Data Uji Genteng Beton}

Pada penelitian telah dilakukan beberapa perlakuan terhadap benda uji. Untuk masingmasing perlakuan pada benda uji menggunakan variasi campuran serat ijuk yang berbeda. Setelah diadakan pengujian terhadap benda uji, yaitu pengujian beban lentur, diadakan pula pengujian daya serap air dan pengujian kerapatan air, yang dilakukan di laboratorium diperoleh data hasil pengujian yang dapat dilihat sebagai berikut : 
a. Hasil pengujian ukuran rata-rata genteng beton

Tabel 4. Data hasil Pengujian Ukuran Rata-rata Genteng Beton.

\begin{tabular}{|c|c|c|c|c|c|}
\hline \multirow{2}{*}{ No. } & \multirow{2}{*}{ Kelompok } & \multicolumn{4}{|c|}{ Ukuran Rata-rata Genteng Beton } \\
\cline { 3 - 6 } & & Berat kg) & Panjang mm & Lebar mm & Tebal mm \\
\hline 1. & I & 3,64 & 420,2 & 340,6 & 11,3 \\
\hline 2. & II & 3,56 & 420,3 & 340,2 & 12,1 \\
\hline 3 & III & 3,57 & 420,3 & 340,3 & 13,4 \\
\hline 4. & IV & 3,65 & 420,4 & 340,3 & 13,05 \\
\hline 5. & V & 3,79 & 420,3 & 340,6 & 13,25 \\
\hline
\end{tabular}

Bila dibandingkan dengan bobot genteng beton tanpa menggunakan batu apung rata-rata $4,5 \mathrm{~kg}$, maka genteng beton yang menggunakan batu apung bobotnya lebih ringan. Dari tabel 4 diatas dapat dilihat bahwa pada perlakuan II merupakan genteng yang paling ringan bobot gentengnya, yaitu rata-rata sebesar $3,56 \mathrm{~kg}$. Maka dapat diketahui besar beban yang akan berkurang terhadap kayu yang menyanggah atap genteng tersebut. Jika jumlah genteng beton yang dipakai untuk 1 meter persegi adalah 10 buah dengan rata-rata sebesar3,56 $\mathrm{kg}$, maka beban yang dapat dikurangi adalah sebesar : Pengurangan bobot genteng : $\frac{4,5-3,56}{4,5} \times 100 \%=20,89 \%$.

Tabel 5. Data hasil Pengujian Ukuran Rata-rata Penampang Tepi Genteng Beton

\begin{tabular}{|c|c|c|c|c|c|c|c|c|}
\hline \multirow{2}{*}{ No. } & Kelompok & \multicolumn{3}{|c|}{ Bagian Penumpangan Tepi } & \multicolumn{3}{c|}{ Kaitan } \\
\cline { 2 - 9 } & & $\begin{array}{c}\text { Lebar } \\
\text { mm }\end{array}$ & $\begin{array}{c}\text { Tebal } \\
\text { mm }\end{array}$ & $\begin{array}{c}\text { Dalam } \\
\text { Alur } \\
\text { mm }\end{array}$ & $\begin{array}{c}\text { Jumlah } \\
\text { Alur } \\
\text { bh) }\end{array}$ & $\begin{array}{c}\text { Panjang } \\
\text { mm }\end{array}$ & $\begin{array}{c}\text { Lebar } \\
\text { mm }\end{array}$ & $\begin{array}{l}\text { Tinggi } \\
\mathbf{m m}\end{array}$ \\
\hline 1. & I & 36,9 & 12,4 & 4,3 & 2 & 57,6 & 21,9 & 13,8 \\
\hline 2. & II & 36,4 & 12,3 & 4,3 & 2 & 57,5 & 22 & 13,7 \\
\hline 3. & III & 36,8 & 12,6 & 4,2 & 2 & 57,9 & 22,1 & 13,4 \\
\hline 4. & IV & 36,3 & 12,3 & 4,3 & 2 & 57,1 & 22,1 & 13,8 \\
\hline 5. & V & 36,4 & 12,4 & 4,2 & 2 & 57,1 & 22,3 & 13,4 \\
\hline
\end{tabular}


Keterangan :

I = Benda uji dengan penggunaan serat ijuk $0 \%$ dari berat semen

II = = Benda uji dengan penggunaan serat ijuk $1 \%$ dari berat semen

III = = Benda uji dengan penggunaan serat ijuk 1,5\% dari berat semen

IV = Benda uji dengan penggunaan serat ijuk $2 \%$ dari berat semen

$\mathrm{V}=$ = Benda uji dengan penggunaan serat ijuk 2,5\% dari berat semen

b. Hasil Pengujian Rata-rata Beban Lentur Genteng Beton

Tabel 6. Data hasil Pengujian Rata-rata Beban Lentur Genteng Beton

\begin{tabular}{|c|l|c|}
\hline No. & \multicolumn{1}{|c|}{ Kelompok } & Beban Lentur Kgf \\
\hline 1. & I. $0 \%$ ijuk dari berat semen & 142 \\
\hline 2. & II. $1 \%$ ijuk dari berat semen & 152,3 \\
\hline 3. & III. $1,5 \%$ ijuk dari berat semen & 154 \\
\hline 4. & IV. $2 \%$ ijuk dari berat semen & 157 \\
\hline 5. & V. $2,5 \%$ ijuk dari berat semen & 199 \\
\hline
\end{tabular}

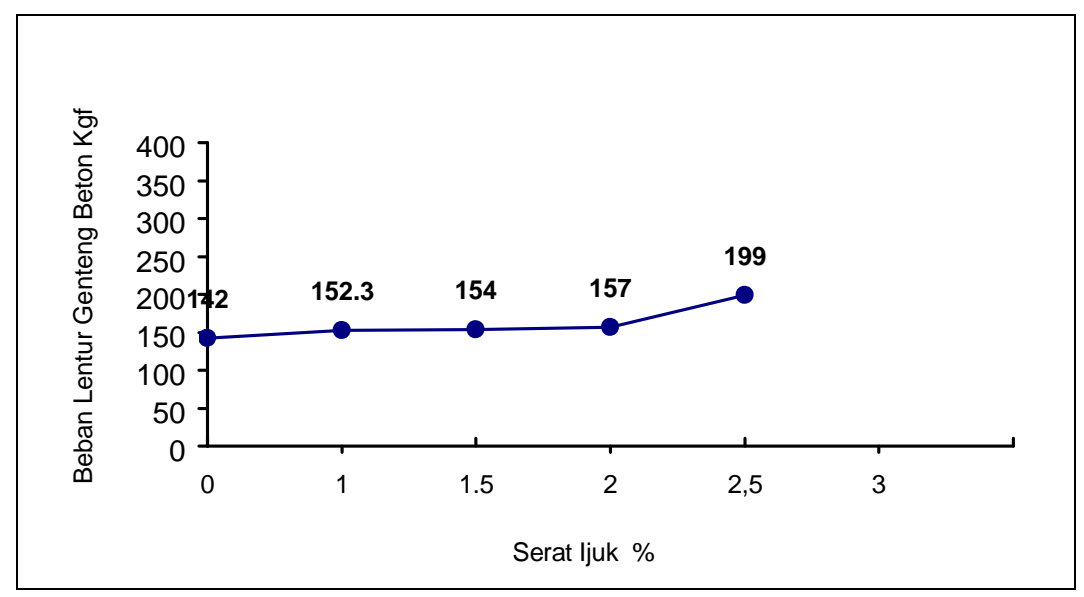

Gambar 4. Grafik Beban Lentur Rata-rata Genteng Beton.

Berdasarkan tabel dan grafik diatas terlihat adanya peningkatan beban lentur. Hal ini menunjukkan adanya kenaikan beban lentur dengan bertambahnya persentase serat ijuk sebagai bahan tambah pada genteng beton.

Pemanfaatan Serat ljuk pada Genteng Beton dengan Menggunakan Batu Apung sebagai Bahan Tambah terhadap Mutu Genteng Beton, Novi Susiawati, Irza Ahmad, Amos Neolaka 
c. Hasil Daya Serap Air Genteng Beton

Tabel 7. Hasil Pengujian Daya Serap Air Rata-rata Genteng Beton

\begin{tabular}{|c|c|c|}
\hline No. & \multicolumn{1}{|c|}{ Kelompok } & Daya Serap Air \% \\
\hline 1. & I. $\quad$ 0\% ijuk dari berat semen & 9,63 \\
\hline 2. & II. $\quad 1 \%$ ijuk dari berat semen & 9,98 \\
\hline 3. & III. $\quad 1,5 \%$ ijuk dari berat semen & 10,91 \\
\hline 4. & V. $\quad 2 \%$ ijuk dari berat semen & 11,87 \\
\hline 5. & V. $2,5 \%$ ijuk dari berat se men & 13,41 \\
\hline
\end{tabular}

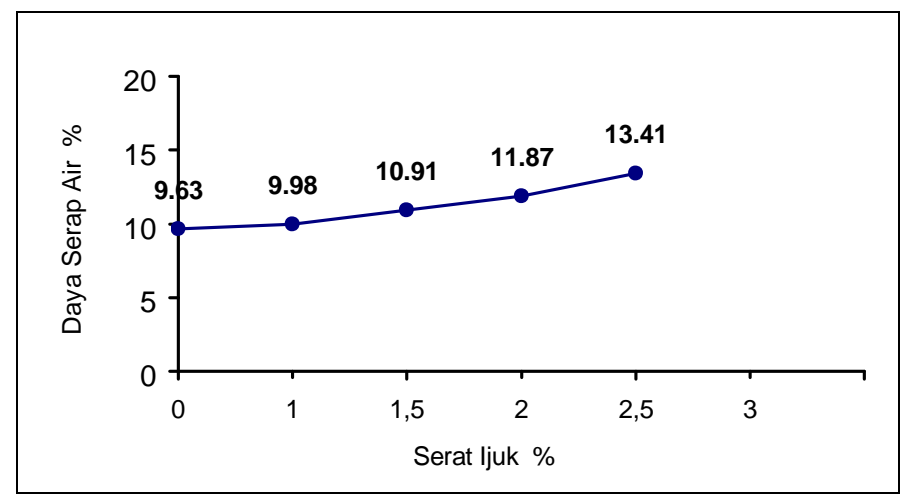

Gambar 5. Grafik Daya Serap Air Rata-rata Genteng Beton.

Dari data tersebut terlihat adanya peningkatan daya serap air genteng beton dengan bertambahnya persentase serat ijuk sebagai bahan tambah pada genteng beton.

Menurut SNI 03-0096-1999, daya serap air untuk genteng beton tidak boleh lebih dari 10\%. Dari grafik diatas dapat dilihat bahwa nilai daya serap air yang memenuhi standar SNI adalah perlakuan I dan perlakuan II, yaitu $0 \%$ dan 1\% serat ijuk dari berat semen sebagai bahan tambah pada genteng beton. 


\section{d. Hasil pengujian Kerapatan Air Genteng Beton}

Data hasil pengujian kerapatan air menunjukkan bahwa kerapatan air untuk semua perlakuan tidak rembes air sehingga dapat dipakai. Menurut SNI 03-0096-1999 menyatakan bahwa apabila genteng basah tetapi tidak terjadi tetesan air maka dinyatakan tahan terhadap perembesan air.

\section{Pengujian Hipotesis}

\section{Pengujian Hipotesis 1}

Pengujian dengan menggunakan uji Analisis Varians ANAVA satu arah untuk beban lentur dengan taraf nyata $\alpha=0,01$ diperoleh hasil pengujian $F$ hitung $>F_{\text {tabel }}$ berarti menolak $\mathrm{H}_{0}$ yang tertera dalam tabel dibawah ini.

Tabel 8. Hasil ANAVA Beban Lentur Genteng Beton

\begin{tabular}{|c|c|c|c|c|c|}
\hline Sumber Varians & dk & JK & KT & $F_{\text {hitung }}$ & $F_{\text {tabel }}$ \\
\hline Rata-rata & 1 & 1288975,7 & 1288975,7 & \multirow{3}{*}{30,35} & \multirow{3}{*}{2,58} \\
\hline Antar Kelompok & 4 & 19334,7 & 4833,68 & & \\
\hline Dalam Kelompok & 45 & 7167,60 & 159,28 & & \\
\hline Jumlah & 50 & \\
\hline
\end{tabular}

Pengujian Analisis Varians untuk daya serap air genteng beton adalah $F_{\text {hitung }}>$ $\mathrm{F}_{\text {tabel }}$ berarti menolak $\mathrm{H}_{0}$ yang tertera dalam tabel dibawah ini.

Tabel 9. Hasil Uji ANAVA Daya Serap Air Genteng Beton

\begin{tabular}{|c|c|c|c|c|c|}
\hline & & & & & \\
\hline Sumber Varians & dk & JK & KT & $\mathbf{F}_{\text {hitung }}$ & $F_{\text {tabel }}$ \\
\hline Rata-rata & 1 & 6224,83 & 6224,83 & & \\
\hline Antar Kelompok & 4 & 93,62 & 23,40 & 119,89 & 2,61 \\
\hline Dalam Kelompok & 45 & 8,78 & 0,195 & & \\
\hline Jumlah & 50 & & & & \\
\hline
\end{tabular}


Dari pengujian hipotesis beban lentur dan daya serap air di atas diperoleh hasil penelitian yaitu : terdapat perbedaan mutu genteng beton dengan penggunaan serat ijuk sebesar $0 \% ; 1 \% ; 1,5 \% ; 2 \%$ dan 2,5\% terhadap berat semen pada genteng beton dengan menggunakan 2,5 batu apung sebagai bahan tambah dan menggunakan mill dengan perbandingan bahan 1 mill : 1 semen Portland.

\section{Pengujian Hipotesis 2}

Berdasarkan perhitungan uji t untuk beban lentur maka diperoleh nilai thitung > trabel atau 28,66 $>2,82$. Sedangkan untuk daya serap air nilai thitung $<$ trabel atau $-0,329<$ 2,82. Maka hasil penelitian adalah nilai optimum mutu genteng beton dengan penggunaan serat ijuk sebesar $0 \% ; 1 \% ; 1,5 \% ; 2 \%$ dan 2,5\% terhadap berat semen pada genteng beton dengan menggunakan 2,5 batu apung sebagai bahan tambah dan menggunakan mill dengan perbandingan bahan 1 mill : 1 semen Portland lebih besar dari nilai Standar Nasional Indonesia.

\section{KESIMPULAN}

Berdasarkan hasil penelitian yang diperoleh, maka dapat disimpulkan sebagai berikut :

1. Penggunaan serat ijuk dengan persentase yang berbeda akan menghasilkan beban lentur yang berbeda pula dengan hasil meningkat dan memenuhi Standar Nasional Indonesia. Dengan kata lain penggunaan serat ijuk pada genteng beton ternyata mampu meningkatkan nilai beban lentur genteng beton yang memenuhi standar.

2. Penggunaan serat ijuk dengan persentase yang berbeda akan menghasilkan daya serap air yang berbeda pula dengan hasil meningkat. Nilai daya serap air genteng beton pada penggunaan persentase $1 \%$ ijuk memenuhi standar, sedangkan penggunaan persentase 1,5\%; $2 \%$ dan 2,5\% ijuk tidak memenuhi standar.

3. Penggunaan serat ijuk sebagai bahan tambah pada genteng beton dapat digunakan sampai persentase $1 \%$ ijuk dari berat semen dengan nilai beban lentur 152,3 $\mathrm{kgf}$ dan daya serap air 9,98\%, karena memenuhi Standar Nasional Indonesia menurut SNI 030096-1999. 
4. Hasil pengujian kerapatan air genteng beton menunjukkan bahwa kerapatan air untuk semua perlakuan tidak rembes air sehingga dapat dipakai.

5. Penggunaan serat ijuk pada genteng beton yang menggunakan batu apung dan mill, terbukti dapat meningkatkan mutu genteng beton.

6. Penggunaan serat ijuk sebagai bahan tambah pada genteng beton dalam penelitian ini ternyata mampu meningkatkan mutu genteng beton. Dan menunjukkan penggunaan serat ijuk pada genteng beton dapat digunakan sampai persentase $1 \%$ ijuk dari berat semen kelompok II karena nilai beban lentur dan daya serapnya memenuhi standar menurut SNI 03-0096-1999. Berdasarkan hasil penelitian, hendaknya perlu dilakukan penelitian lebih lanjut mengenai penambahan serat alami lainnya dengan persentase yang lebih bervariasi, sehingga hasil yang dicapai lebih optimal.

\section{DAFTAR PUSTAKA}

Balai Penelitian Bahan, Petunjuk Teknis Pembuatan Serat Semen, Jakarta: Dept. Perindustrian

Balai Penelitian Bahan Dinas Perindustrian DKI Jakarta, 1996. Petunjuk Teknis Pembuatan Genteng Beton. Jakarta : Dept. Perindustrian.

Irfan, 2003,_Studi Pemanfaatan Ampas Tebu Bagase Sebagai Bahan Tambahan Pembuatan Genteng Beton, Jakarta: UNJ

Manggasa, Andarias, 1993. Penerapan Teknologi Genteng Beton Dari Batu Apung. Ujung Pandang : Balai Industri.

Manggasa, Andarias. 1996. Subtitusi Batu Apung Pada Pembuatan Genteng Beton Sebagai Salah Satu Alternatif Pengurangan Bobot. Jakarta : Majalah Kimia, No. 55, Juni 1996.

Ramoko, 1996, Studi pemanfaatan Serabut Kelapa Sebagai Bahan Tambahan Pada Pembuatan Genteng Beton Dalam Kaitannya Dengan Kekuatan Lentur Genteng Beton, Jakarta: UNJ

SNI 03-0096-1999, 1999, Genteng Beton. Jakarta : BSN.

Ulumudin. , 2004, Pengaruh Penambahan Serat ljuk Pada Pembuatan Paving Block Terhadap Kuat Tekan. Jakarta : UNJ. 